Andrew Ter Ern Loke*

\title{
On the Divine Preconscious Model of the Incarnation and concrete-nature Christology: A reply to James Arcadi
}

DOI 10.1515/nzsth-2017-0002

Summary: In a recent article published in NZSTh, James Arcadi offers an assessment of the Divine Preconscious Model of the Incarnation. Arcadi objects that, because I aver that this model runs on a concrete-nature account of natures, I am not able to maintain the full humanity of Christ. I argue that Arcadi's objections are not compelling, and while I appreciate his intention to offer constructive feedback, I explain that his suggestions that I embrace a form of neo-Apollinarianism by adopting the abstract-nature perspective of natures are unmotivated and disadvantageous.

Keywords: Coherence of the Incarnation, Divine Preconscious Model, concretenature, abstract-nature, Apollinarianism

Zusammenfassung: In einem kürzlich in der NZSth veröffentlichten Artikel bietet James Arcadi eine Einschätzung des Divine Preconscious Model der Inkarnation. Arcadi wendet ein, dass ich aufgrund meiner Behauptung, dieses Modell basiere auf einem concrete-nature Verständnis der Naturen, nicht in der Lage bin, die vollständige Humanität Christi zu erhalten. Ich versuche zu zeigen, dass Arcadis Einwände nicht zwingend sind und ich erkläre, dass auch, wenn ich seine Absicht, konstruktives Feedback anzubieten, schätze, sein Vorschlag, dass ich eine Form des Neo-Apollinarianismus vertrete oder doch die abstract-nature Perspektive der Naturen annehmen soll, unbegründet und nachteilig ist.

Schlüsselwörter: Coherence of the Incarnation, Divine Preconscious Model, concrete-nature, abstract-nature, Apollinarianismus

*Corresponding author: Andrew Ter Ern Loke, The University of Hong Kong, Office address: Room 1001, 10/F, Run Run Shaw Tower, Centennial Campus, The University of Hong Kong, Pokfulam Road, Hong Kong, E-Mail: andyloke@hku.hk 


\section{Introduction}

In an article recently published in this journal, James Arcadi offers an assessment of the Divine Preconscious Model of the Incarnation. ${ }^{1}$ While appreciative of my contribution, Arcadi objects that, because I aver that this model runs on a concrete-nature account of natures, I am not able to maintain the full humanity of Christ. He suggests two ways I might be able to maintain the integrity of my model, either by embracing a form of neo-Apollinarianism or by adopting the abstract-nature perspective of natures. In this article, I shall show that Arcadi's objections are not compelling and that there is insufficient motivation for embracing his suggestions.

\section{On the meaning of abstract nature and concrete nature}

To begin, Arcadi's exposition of abstract nature and concrete nature is problematic. Arcadi traces the terminologies of concrete-nature and abstract-nature views back to Alvin Plantinga's 1999 article “On heresy, mind, and truth.” He cites Plantinga, Oliver Crisp and Jonathan Hill for his understanding of abstract nature and concrete-nature, and claims that "in distinction from the abstract-nature view, the concrete-nature perspective begins not with properties, but with a concrete particular."2 In a footnote, he asserts that "this is logical priority not chronological. The possession of a concrete particular nature is logically prior to the possession of certain properties." 3

However, it should be noted that Plantinga does not say that such a logical priority is necessary for the concrete nature perspective. Plantinga writes that on the concrete-nature view, "what he [the Word] assumed was a human nature, a specific human being. What happened when he became incarnate is that he adopted a peculiarly close and intimate relation to a certain concrete human being, a 'human nature' in the sense of a human being." 4

1 James ArCadi, "Kryptic or cryptic? The Divine Preconscious Model of the Incarnation as a concrete-nature Christology," Neue Zeitschrift für Systematische Theologie und Religionsphilosophie 58(2) (2016), 229-243.

2 Ibid, 232.

3 Ibid, 232n.11.

4 Alvin Plantinga, “On heresy, mind, and truth,” in Faith and Philosophy 16(2) (1999), 183-4. 
Plantinga does not say concrete-nature perspective begins with a concrete particular. Rather, what he says is that the concrete-nature perspective refers to a concrete particular when the term nature is used.

Arcadi also cites Oliver Crisp, who understands concrete nature as follows

“A concrete-nature view is one that states that Christ's human nature is a concrete particular, perhaps a human body, but, traditionally, a human body and human soul distinct from the Word." 5

Like Plantinga, Crisp (whose view as stated above is followed by myself) ${ }^{6}$ does not say concrete-nature perspective begins with a concrete particular. Rather what he says is that the concrete-nature perspective refers to a concrete particular when the term nature is used.

It should also be noted that Crisp's understanding of concrete nature is slightly different from Plantinga's. Unlike Plantinga, Crisp does not say that the concrete nature is a specific human being that was adopted into a close relationship by the Word. This is to be commended, for Plantinga's description seems to imply Nestorianism or Adoptionism.

Arcadi cites another description by Jonathan Hill:

"Defenders of relational models often speak in terms of the Son acquiring a nature. Such language takes 'nature' to mean a particular thing. On this conception, my human nature is distinct from your human nature. However, an alternative definition of 'nature' exists, on which it is a set of essential properties. On this conception, a 'nature' is a universal, so my human nature is identical with your human nature. It is usual, in contemporary writing on the incarnation, to call the former understanding of 'nature' 'concretism', and the latter 'abstractism”"?

Again, Hill does not talk about logical priority, but rather meaning and reference, as he says 'such language takes 'nature' to mean a particular thing.'

Thus, none of the authorities cited by Arcadi supports his view of logical priority. In any case, one might ask, what is the justification for thinking that such a logical priority exists in reality? Such a priority may reflect how Arcadi thinks about concrete human nature, but why is it necessary in reality?

5 Oliver Crisp, Divinity and Humanity: The Incarnation Reconsidered, Current Issues in Theology (Cambridge: Cambridge University Press, 2007), 41.

6 Andrew Ter Ern Lоке, A Kryptic Model of the Incarnation (London: Routledge, 2014), 68.

7 Jonathan Hill, "Introduction", in Anna Marmadoro and Jonathan HiLl, The Metaphysics of the Incarnation (Oxford: Oxford University Press, 2011), 11. 
Arcadi attempts to justify his description of the concrete-nature view by considering the action of humans and alligators crushing bits of chicken in their respective jaws. He writes,

\begin{abstract}
"On the concrete-nature view, despite the similarities of these two actions (I and an alligator crushing bits of chicken in our respective jaws), they are not the same kind of action because the capacity for our actions emerge from our different kind-natures. It is our natures, my human nature and the alligator's alligator nature, that endow us with the capacity to perform this action, but they are not the same capacity because they are in virtue of different natures. Thus, I am unable to alligator-ly crush small bits of chicken, just as the alligator is not humanly able to crush small bits of chicken. The concrete nature view states that all possessors of natures possess certain capacities and powers in virtue of having those natures, but the capacities are due to the nature rather than the nature being constituted by the having of certain capacities."
\end{abstract}

Arcadi's view does not seem to make sense. The fact is that my capacities are not endowed by my human concrete nature; rather my human concrete nature together with its capacities are brought into existence by prior causes. For example, where human capacity for consciousness is concerned, one might say that a human (e.g. Peter) has this capacity because God (the ultimate source of all things) brought him into existence endowed with this capacity, using a procreation process involving his parents and their genes (and also their souls, if one holds to Traducianism). This procreation process generated an individual instance of concrete human nature, viz. Peter's, together with certain capacities. In the case of Christ, his human nature with its capacity for consciousness resulted from a virginal conception involving the supernatural work of the Holy Spirit and, my model would say, Christ's consciousness acquiring human properties that were newly created together with the creation of a human preconscious and human body (see below). This process generated an individual instance of concrete human nature, viz. the human nature of Christ.

Arcadi claims that "[a]t bottom, when deciding what view of nature one wishes to adopt, one can ask a fundamental distinguishing question of an entity: does it have properties that entail membership in a kind or is it a member of a kind that then entails certain properties? If one affirms the former one is working with an abstract-nature conceptual infrastructure, if the latter then one endorses the concrete-nature perspective."

This claim seems confused. Both properties and kinds are abstract; the question has no bearing on the abstract-nature/concrete-nature distinction. I do not

8 ARCAdi, “Kryptic or cryptic?”, 234.

9 Ibid. 
see why someone who states that Christ's human nature is a concrete particular cannot say that the (human) concrete particular has properties that entail membership in a (human) kind.

In summary, Arcadi's views about logical priority and starting points are unjustified. I would reply that the distinction between concrete and abstract nature view is simply a matter of reference: whether one is referring to a concrete particular or a property when one uses the term 'nature'. On the concrete nature view, a concrete human nature is simply a concrete particular with human properties. This is true regardless of where the properties of this concrete particular came from, i.e. regardless of the source and processes resulting in this concrete particular possessing these properties. The human consciousness could have come about as the result of acquiring of properties in the manner described by myself (see the next section); this view avoids the problem of Nestorianism or Adoptionism. I mention that the motivation of adopting the concrete nature view is that it allows for a clear explication of how contradictory properties can be exemplified by Christ in two different respects: in respect of his divine nature (or qua God) and in respect of his human nature (or qua man). ${ }^{10}$ As long as natures are understood as concrete parts of Christ, this motivation is met; there is no need to hold to Arcadi's views about logical priority and starting points.

\title{
III Concerning Arcadi's specific criticisms of the Divine Preconscious Model
}

Moving on to Arcadi's specific criticisms of DPM, Arcadi writes,

\begin{abstract}
"I think there is a fundamental inconsistency in the DPM as stated if it is explicated with a concrete-nature view in mind. It seems to be a necessary feature of an instance of human nature that it include the capacity for consciousness...a conscious is necessary for a nature being construed as a complete human nature. On the concrete-nature picture of natures, the possession of every necessary property of a nature is logically posterior to possession of the concrete particular instance of that nature."11
\end{abstract}

Arcadi goes on to argue that

“On Loke's version of the DPM, the one consciousness of Christ is possessed by Christ in virtue of his divine nature, he is not conscious in virtue of his human nature, he is only

10 LoKe, A Kryptic Model of the Incarnation, 73.

11 ARCADi, “Kryptic or cryptic?”, 238. 
conscious in virtue of his divine nature. But then given the concrete-nature picture of natures, and a human consciousness being a necessary feature of human nature, Christ did not take on a complete human nature in the incarnation. Christ was conscious, he was divinely conscious, but he was not humanly conscious, and was thus not fully human." ${ }^{2}$

As evident from the first quotation, Arcadi's criticism is based on his view that, 'on the concrete-nature picture of natures, the possession of every necessary property of a nature is logically posterior to possession of the concrete particular instance of that nature.' This view is based on his understanding of logical priority concerning concrete nature, which is unjustified and unnecessary as explained in the previous section of this paper. With regards to the second quotation, to say that Christ took on a complete concrete human nature at the Incarnation risks Adoptionism. It is better to say ${ }^{13}$ that Christ possessed a complete concrete human nature at the Incarnation as a result of his consciousness acquiring human properties that were also newly created together with the creation of a human preconscious and human body. Given that Christ's conscious had a human aspect, he was humanly conscious. It should be noted that my view does not deny that there was a human consciousness in Christ. What it denies was that there was a pre-existing human consciousness which was adopted by Christ. On my view, Christ's human consciousness did not come about by adopting a complete human being, rather it came about by the consciousness of the pre-existing Second Person of the Trinity acquiring certain human properties at the Incarnation.

Arcadi complains that, by making this sort of move, I am in effect affirming an abstract nature view against my wishes. Arcadi writes,

"Here it seems as though the divine consciousness piled on $\mathrm{H}$ properties in order to be human." 14 "Further, Loke states that Christ had a full human nature, "in virtue of the aspect of his consciousness which had human properties, the human preconscious (part B of Jesus' preconscious), and human body,"... Recall from above that on the concrete-nature view an entity has properties in virtue of one's nature, but here Loke describes Christ as having a nature in virtue of having certain properties; this is already an abstractist way of characterizing things." 15

In reply, as explained previously, it can be argued that the abstract-nature/ concrete-nature distinction is merely a matter of reference and does not need to concern logical priority or process of formation.

\footnotetext{
12 Ibid.

13 LoKe, A Kryptic Model of the Incarnation, 73.

14 ARCADI, “Kryptic or cryptic?”, 242.

15 Ibid.
} 
Arcadi notes that I state that "the 'human soul' and the divine nature were two distinct aspects of the immaterial part of Christ," and that "The human aspect had all the properties essential to a human soul; the divine aspect had all the properties essential to a divine soul; and these two aspects were distinct from one another.” Arcadi objects

"Yet it is unclear in this analysis what ontological work "aspects" does. It does a lot of work in linguistically separating the divine nature from the human soul. But since they are both just components of the immaterial part of Christ, the soul is not an entity in its own right as it is on the concrete view, it would seem easier to adopt an abstactist view of the human soul of Christ." ${ }^{16}$

But what does 'an entity in its own right' mean? If it means an independent and separate entity, this would imply that Arcadi thinks that the concrete view entails that the Incarnate Christ has a divine soul and a human soul that are independent and separate from each other, which implies two persons and Nestorianism. Against this understanding, what one needs to ask is this: why does the human soul has to be an independent and separate entity on the concrete view? As noted earlier, Crisp describes a concrete-nature view as "one that states that Christ's human nature is a concrete particular, perhaps a human body, but, traditionally, a human body and human soul distinct from the Word." My view fits this description. On my view, Christ's human soul is distinct but not independent and separate from the Word. It is distinct in being a distinct concrete aspect of the one soul of Christ, and it is not independent and separate because it is a component of the one soul of Christ. Thus there is no Eutychianism or Nestorianism.

Arcadi points out that my view fits certain aspects of what Crisp describes as the "Alvinized abstract-nature view”, “an exposition of Plantinga's view, as such, In assuming human nature he [the Word] assumes whatever property or properties are necessary and sufficient for the Word to become the human soul that exists in the body of Christ...the Word becomes the soul of the body of Christ." ${ }^{17}$ Now as noted earlier I do affirm that the consciousness of the pre-existing Word acquiring certain human properties at the Incarnation, while retaining a divine aspect of his soul. However, what Arcadi does not note is that my view is different from an "Alvinized abstract-nature view" in a crucial way, in that on my view nature refers to concrete particular, and thus should not be regarded as an abstract-nature view. The similarities between my view and the "Alvinized abstract-nature view" merely lies in the process of formation: both involve an

16 ARCAdi, “Kryptic or cryptic?", 242-243; italics mine.

17 Ibid, 243, citing Crisp, Divinity and Humanity, 50. 
acquisition of human properties by the Word. However, as argued in the previous section, a concrete human nature is simply a concrete particular with human properties, regardless of the processes resulting in this concrete particular possessing these properties. Thus, my view should still be regarded as a concrete-nature view.

Moreover, given that my view fits Crisp's description in having a human soul distinct from the Word, it is not Apollinarian nor neo-Apollinarian. Rather, Christ has a concrete and complete human nature which includes a human conscious, not merely “a divine consciousness that 'functions as' a human consciousness' as Arcadi thinks. ${ }^{18}$ On my view, Christ is not only able to constrain his consciousness to only execute those things a human consciousness could do, as Arcadi noted. ${ }^{19}$ Rather, its consciousness has human aspect and properties such as the capacity to experience physical pain, to have sensations through physical organs and to have the desires for food, for sleep, etc. ${ }^{20}$ Given this, Christ evidently has a human consciousness.

\section{Conclusion}

In conclusion, Arcadi's objections to my view are unwarranted. Moreover, his suggestion that I embrace a form of neo-Apollinarianism cannot be adopted, given that on my view Christ has a human soul distinct from the Word. His suggestion that I adopt the abstract-nature perspective of natures would (as he notes) have the troublesome consequence of requiring myself to re-envision how to address the problem of contradictory attributes, ${ }^{21}$ and is in any case unnecessary. Nevertheless, I deeply appreciate Arcadi's detailed engagement of my work and his desire to offer a constructive feedback.

\footnotetext{
18 Ibid.

19 Ibid.

20 Lоке, A Kryptic Model of the Incarnation, 69.

21 ARCADI, “Kryptic or cryptic?”, 243.
} 